\title{
Spatial distribution and activities of the estuarine dolphin Sotalia guianensis (van Bénédén, 1864) (Cetacea, Delphinidae) in Pontal Bay, Ilhéus, Bahia, Brazil
}

\author{
Urânia Amaral dos Santos', Martin Roberto Alvarez, Ana Cristina Schilling ${ }^{2}$,
} Gil Marcelo Reuss Strenzel ${ }^{3}$ \& Yvonnick Le Pendu ${ }^{1,4}$

${ }^{1}$ Grupo de Pesquisa em Mamíferos Aquáticos de Ilhéus, Programa de Pós-graduação em Zoologia, Departamento de Ciências Biológicas, Universidade Estadual de Santa Cruz-UESC, Campus Soane Nazaré de Andrade, Rod. Ilhéus-Itabuna, Km 16, CEP 45662-900, Ilhéus, BA, Brazil

${ }^{2}$ Grupo de Estudos da Mata Atlântica, Departamento de Ciências Exatas e Tecnológicas, Universidade Estadual de Santa Cruz-UESC, Campus Soane Nazaré de Andrade, Rod. Ilhéus-Itabuna, Km 16, CEP 45662-900, Ilhéus, BA, Brazil

${ }^{3}$ Grupo de Pesquisa em Mamíferos Aquáticos de Ilhéus, Laboratório de Análise e Planejamento Ambiental, Departamento de Ciências Agrárias e Ambientais, Universidade Estadual de Santa Cruz - UESC, Campus Soane Nazaré de Andrade, Rod. Ilhéus-Itabuna, Km 16, CEP 45662-900, Ilhéus, BA, Brazil

${ }^{4}$ Corresponding author: Yvonnick Le Pendu, e-mail: yvonnick@uesc.br

SANTOS, U.A., ALVAREZ, M.R., SCHILling, A.C., STRENZEL, G.M.R. \& LE PENDU, Y. Spatial distribution and activities of the estuarine dolphin Sotalia guianensis (van Bénédén, 1864) (Cetacea, Delphinidae) in Pontal Bay, Ilhéus, Bahia, Brazil. Biota Neotrop. 10(2): http://www.biotaneotropica.org.br/ v10n2/en/abstract?article+bn01310022010.

\begin{abstract}
We analyzed the influence of time, tide and water depth on the activity and spatial distribution of estuarine dolphins Sotalia guianensis in Pontal Bay, Ilhéus, Brazil. Direct observations were carried out at four fixed points from January to December of 2006. Estuarine dolphins were sighted in 11 out of 12 months and in $30 \%$ of 181 sampling periods. The average group size, which was $3.75 \pm 1.59(\mathrm{n}=64)$, did not vary significantly by month (Kruskal-Wallis, $\mathrm{H}=10.6729 ; \mathrm{p}=0.3836$ ). Infants and adults represented 18 and $82 \%$ of the individuals whose age we were able to determine, respectively. Estuarine dolphins were more frequently present than expected in areas deeper than $3 \mathrm{~m}$ (regression GLM, $\mathrm{z}=3.773 ; \mathrm{p}=0.0002$ ). The animals were more frequently observed between 7:00 and 8:00 AM and between 3:00 and 5:00 PM $\left(\mathrm{X}^{2}=83.815 ; \mathrm{p}<0.0001\right)$. Their presence in the bay tripled between the fourth hour of the flood and high tide, remaining elevated during the ebb tide $\left(X^{2}=22.152 ; p=0.02\right)$. The tide also influenced the animals' feeding and travelling direction, mainly toward the open see during the flood and to the back of the bay during others stages. Further studies are necessary to analyze the influence of the hydrographic characteristics of Pontal Bay on the spatio-temporal distribution of estuarine dolphins and their prey.
\end{abstract}

Keywords: dolphin, behavior, time of the day, tide, water depth, estuarine fauna.

SANTOS, U.A., ALVAREZ, M.R., SCHILLING, A.C., STRENZEL, G.M.R. \& LE PENDU, Y. Distribuição espacial e atividades do boto-cinza, Sotalia guianensis (van Bénédén, 1864) (Cetacea, Delphinidae) na Baía do Pontal, Ilhéus, Bahia, Brasil. Biota Neotrop. 10(2): http://www.biotaneotropica.org.br/v10n2/pt/ abstract?article+bn01310022010.

Resumo: Analisamos a influência do horário, da maré e da profundidade de água sobre a atividade e a distribuição espacial do boto-cinza Sotalia guianensis na Baía do Pontal, Ilhéus, Brasil. Observações diretas foram realizadas de quatro pontos fixos de janeiro a dezembro de 2006. Botos-cinza foram avistados em 11 dos 12 meses de observação e em $30 \%$ dos períodos de amostragem. O tamanho médio dos grupos foi de 3,75 $\pm 1,59 ;(n=64)$ e não variou significativamente em função do mês (Kruskal-Wallis, $H=10,6729 ; \mathrm{p}=0,3836$ ). Infantes e adultos representaram respectivamente 18 e $82 \%$ dos indivíduos cuja idade foi determinada. Os botos-cinza foram mais freqüentes em áreas com profundidade superior a $3 \mathrm{~m}$ do que esperado (regressão GLM, $\mathrm{z}=3,773 ; \mathrm{p}=0,0002$ ). Os animais foram mais observados entre 7 e 8 horas e entre 15 e 17 horas $\left(X^{2}=83,815 ; p<0.0001\right)$. A frequência do boto-cinza na baía triplicou entre a quarta hora de maré enchente e a preamar e sua presença se manteve alta durante a maré de vazante $\left(X^{2}=22,152 ; p=0,02\right)$. A maré influenciou também a direção de forrageamento e deslocamento dos botos-cinza, principalmente para o mar aberto durante o preamar e o fundo da baía em outras fases da maré. É necessário estudar a influência das características hidrográficas da Baía do Pontal sobre a distribuição spatio-temporal de $S$. guianensis e suas presas.

Palavras-chave: golfinho, comportamento espacial, horário, maré, profundidade, fauna estuarina. 


\section{Introduction}

The estuarine dolphin Sotalia guianensis (Van Bénéden 1864) is present in a seemingly continuous distribution from the coast of Nicaragua to the State of Santa Catarina in Southern Brazil (Flores \& Da Silva 2009). The species occurs mostly in bays and estuaries but can also be found in open coastal areas (Flores \& Da Silva 2009). Due to its coastal habits, it is vulnerable to almost all human activities (Flores \& Da Silva 2009), particularly fishing and boat traffic (Reeves et al. 2003). The International Union for the Conservation of Nature (IUCN) considers the threat assessment of the genus Sotalia as "Data Deficient" (Reeves et al. 2008), but a "near threatened" category for Sotalia guianensis has recently been proposed (Rossi-Santos \& Reis 2008).

The structure and distribution of cetacean groups have been related to a variety of environmental factors, such as surface temperature, water salinity (Selzer \& Payne 1988), water depth (Edwards \& Schnell 2001, Simão \& Poletto 2002, Flores \& Bazzalo 2004, Azevedo et al. 2007), change in depth (Hui 1985) and tidal variation (Mendes et al. 2002). The estuarine dolphin uses areas with steep seafloor relief intensely, allowing it to trap fish schools and reduce energy expenditure during foraging (Monteiro-Filho 1995, Cremer 2000, Bonin 2001, Lodi 2003a). Seafloor relief and substratum can affect prey distribution and are important factors in the choice of foraging places within a bay or estuary (Lodi 2003a). Studies have corroborated that many environmental variables that have been identified for other cetacean species, such as tide state (Araújo et al. 2003), water depth (Geise et al. 1999, Lodi 2003a, Domit 2006) and water temperature (Daura-Jorge et al. 2004, Rossi-Santos 2006), can also influence the occurrence and habitat use of $S$. guianensis.
Some preliminary studies carried out in Pontal Bay (Ilhéus, Brazil) have shown that estuarine dolphins regularly frequent the area in groups usually consisting of 3 to 4 individuals (Batista 2001, Santos 2001). This study analyzes the occurrence of $S$. guianensis in Pontal Bay in relation to tidal movement, water depth and time of day.

\section{Material and Methods}

The Cachoeira, Fundão and Santana rivers form an estuarine system popularly known in its low part as Pontal Bay ( $14^{\circ} 48^{\prime} \mathrm{S}$ and $\left.39^{\circ} 02^{\prime} \mathrm{W}\right)$, located in the municipality of Ilhéus on the southern coast of Bahia, Brazil. The estuary is silty, with mangroves and some sand banks at the position of the lower alluvial terrace (Nacif et al., 2003). The local climate is Af (tropical rain forest) according to the Köppen classification scheme. The upper part of the estuary presents high concentrations of phosphorus, dissolved oxygen and fecal coliforms (Fidelman 2005) as well as high concentrations of inorganic nutrients in Pontal Bay (Silva 2007, Eça et al., 2008). Pontal Bay is $40 \mathrm{~km}^{2}$, and the water depth varies from 1-17 m, according to the DHN 1201 nautical chart.

Behavioral and environmental data collection was carried out from January to December of 2006. Each sampling session was conducted during alternate periods, i.e., from 6:00 to 10:00 AM, 10:00 AM to 2:00 PM or 2:00 to 6:00 PM. Observations were carried out sequentially or simultaneously (see below) from four fixed points (A, B, C, D), allowing visualization of most of the bay (Figure 1). Each sampling period consisted of 16 successive instantaneous scan samplings (Altmann 1974, Martin \& Bateson 2007); four scans were conducted every 15 minutes from the same point, and the interval between the last scan of a point and the first scan of the following point was 15 minutes.

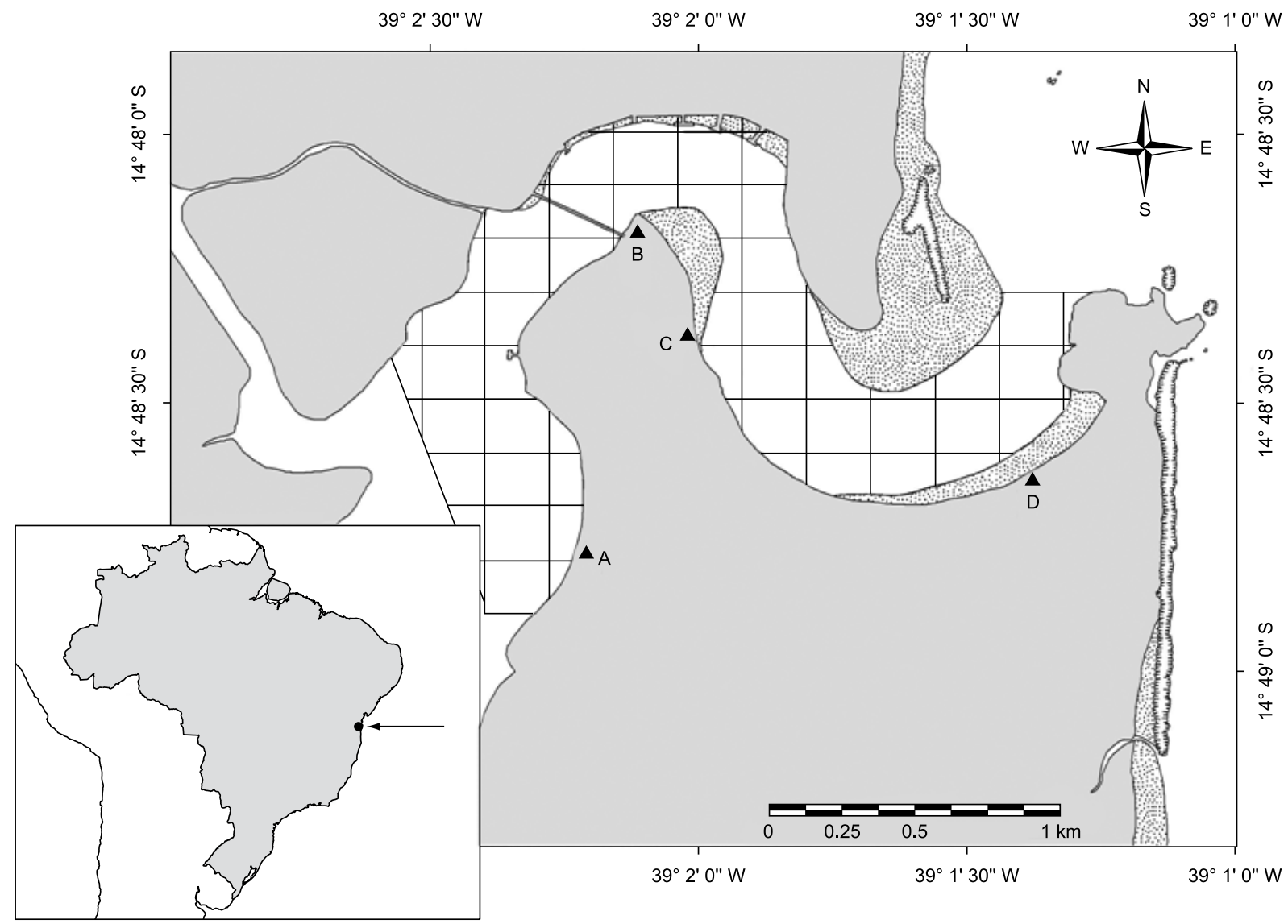

Figure 1. The study area in Pontal Bay, Ilhéus, Brazil and the four observation points A, B, C and D. 
From January to August of 2006, data were collected an average of four times per week by an observer (U.A. dos Santos), passing through the four fixed observation points (A, B, C and D or, alternatively, D, C, B and A). From September to December of 2006, observations were carried out twice a week by four trained observers (U. A. dos Santos and three others) who were positioned at a fixed point for four hours in order to record the occurrence of several groups in different areas of the bay. For the purpose of the present study and to maintain homogeneous data collection, only the first four scans by the observer stationed in the first fixed point (A or D), the fifth to eighth scans by the second observer (stationed in B or C), the ninth to the twelfth scans by the third observer (stationed in $\mathrm{C}$ or $\mathrm{B}$ ) and the thirteenth to the sixteenth scans by the fourth observer (stationed in D or A) were considered for analysis.

Each scan sampling consisted of registering the time, location, composition in age classes of each observed group of estuarine dolphins and the activity carried out by each individual. The location of each group was plotted on the DHN 1201 (1:12500) nautical chart. The area of observation was subdivided into 59 quadrants of six-second squares $\left(33,000 \mathrm{~m}^{2}\right)$ to facilitate plotting. The limit of each quadrant was easily identified using visual cues like buildings, trees, or decks, minimizing the risk of error when localizing the groups. The use of binoculars was rarely necessary to confirm the location of a group.

The age class of each individual was visually estimated, taking into consideration body size and coloration pattern (Simões-Lopes 1988, Da Silva \& Best 1996, Randi et al. 2008); individuals were classified as infants (with half to three fourths of the total length of an adult, adults (with more than three fourths of the total length of an adult) or undetermined (when it was not possible to define the age class). We recorded when the animals were feeding or travelling (Bearzi 2005 for definitions), in the direction of the entrance or back of the bay. Only the first sighting of each group was considered in the analyses. For each scan sampling, the number of hours from the last low tide and the direction of flow were recorded, using the tide table of the Porto do Malhado region, Ilhéus, published by the Hydrography and Navigation Directory of the Brazilian Navy. Twelve tide states were defined: 0 to 6 during flood $(0$, from the time of low astronomic tide to one hour later, to 6 , beginning six hours after low tide to high tide) and 7 to 11 during flood (7, from the time of high astronomic tide to one hour later, to 11, beginning six hours after high tide to the next low tide).

A geographically referenced database of the study area was made through the ESRI Arc Gis 9.3 program to investigate the relationships between the frequency of sighted individuals and the average depth of each quadrant. For this purpose, the bathymetric data of the nautical chart was vectorized and interpolated, applying the TIN (Triangulated Irregular Network) algorithm (Burrough \& Mcdonnell 1998). The average depth of each quadrant was then extracted to a database. To analyze the use of the area, i.e., the number of individuals per quadrant relative to water depth, a regression was carried out with Poisson error through generalized linear models. Quadrants with an average water column of less than $40 \mathrm{~cm}(\mathrm{n}=6)$ were excluded from analysis. Individuals more than $100 \mathrm{~m}$ away were considered as being part of different groups (adapted from Shane 1990, Mann 1999). The data regarding the number of individuals observed per scan sampling according to time were homogenized: the average number of individuals observed per hour was generated by 1,000 permutations of 200 scans, and the average curve was adjusted, carrying out an interpolation of Cubic Spline type. The same procedure was used to analyze variations in the number of individuals observed by the tide state. The permutation analyses were carried out using $\mathrm{R}$ version 2.7.1. Chi-square and Kruskal-Wallis non-parametric tests were carried out using Bioestat 5.0 software.

\section{Results}

The presence of estuarine dolphins in the bay was registered in 52 out of 181 sampling periods and in 88 out of 2,894 scan samplings. The dolphins were sighted in every month except November. The sighting probability of estuarine dolphins was higher in September and October (Figure 2) than in other months.

A total of 64 groups ranging from 1 to 7 individuals $(3.75 \pm 1.59)$ were sighted, totaling 240 estuarine dolphins, but the same individuals may have been registered on different days. The monthly variation in group size was not significant (Kruskal-Wallis, $\mathrm{H}=10.6729$; g.l. = 10; $\mathrm{P}=0.3836$ ). Infants and adults represented 18 and $82 \%$, respectively, of the individuals whose ages were determined. Infants and adults were identified every month. We were unable to determine the age of $19 \%$ of the individuals.

A larger frequency of estuarine dolphins was found in deeper areas (GLM regression with Poisson error: Depth $=1.46231+0.13043$ (individuals); $\mathrm{z}=3.773 ; \mathrm{p}=0.0002$ ). Almost half of the sightings (49.3\%) occurred in quadrants with 3 to $6.79 \mathrm{~m}$ of mean depth which only represented $32 \%$ of the available quadrants (Figure 3 ).

The number of estuarine dolphins recorded in the area varied according to the time of day: animals were more frequently observed between 7:00 and 8:00 AM and between $3: 00$ and 5:00 PM $\left(\mathrm{X}^{2}=83.815\right.$; d.f. $\left.=11 ; \mathrm{p}<0.0001\right)$. As the distribution of group size was constant during the day, the larger frequencies of estuarine dolphins registered in the morning and afternoon are due to a larger number of groups frequenting the bay (Figure 4).

The estuarine dolphins frequented Pontal Bay in a heterogeneous way relative to tidal state $\left(\mathrm{X}^{2}=22.152 ;\right.$ g.l. $\left.=11 ; \mathrm{p}=0.02\right)$. During the first four hours of flood tide, the number of individuals decreased gradually, before tripling between the fourth hour of flood and the high tide. The number of individuals recorded remained high during the ebb tide (Figure 5).

A total of 348 individual activity states were registered and classified as travelling $(49.7 \%)$ or feeding $(50.3 \%)$. The tide influenced the animals' feeding and travelling direction. During the first four hours of flood, the proportion of individuals performing any of these activities toward the back of the bay increased gradually, from 18 to $83 \%$ (Figure 6). During the two following hours, this direction was reversed and most of individuals $(87.5 \%)$ were oriented to the entrance of the bay during the high tide (state 6), mainly engaging in feeding activity (69\%). At the beginning of the ebb tide (state 7), 76\% of the individuals were swimming upstream, toward the back of the bay. This proportion decreased gradually during the ebb tide.

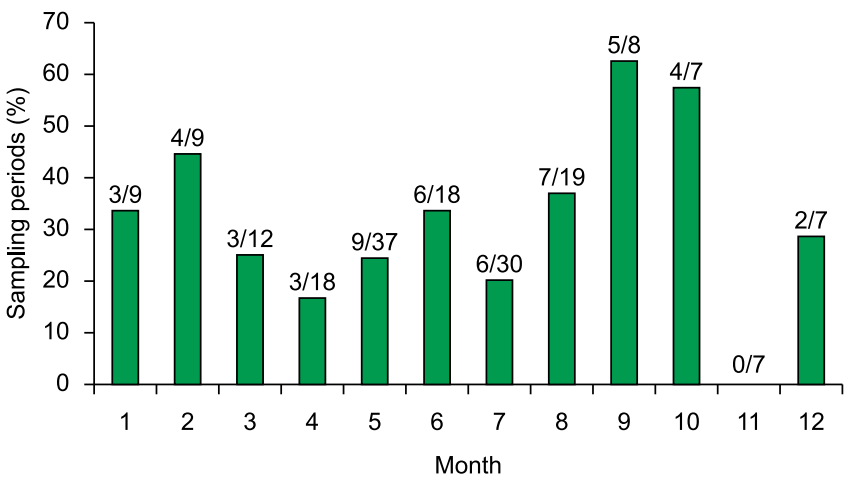

Figure 2. Monthly proportion of sampling periods with sighting of estuarine dolphins at Pontal Bay, Ilhéus in 2006. Labels: number of sampling periods with sightings/total number of sampling periods. 


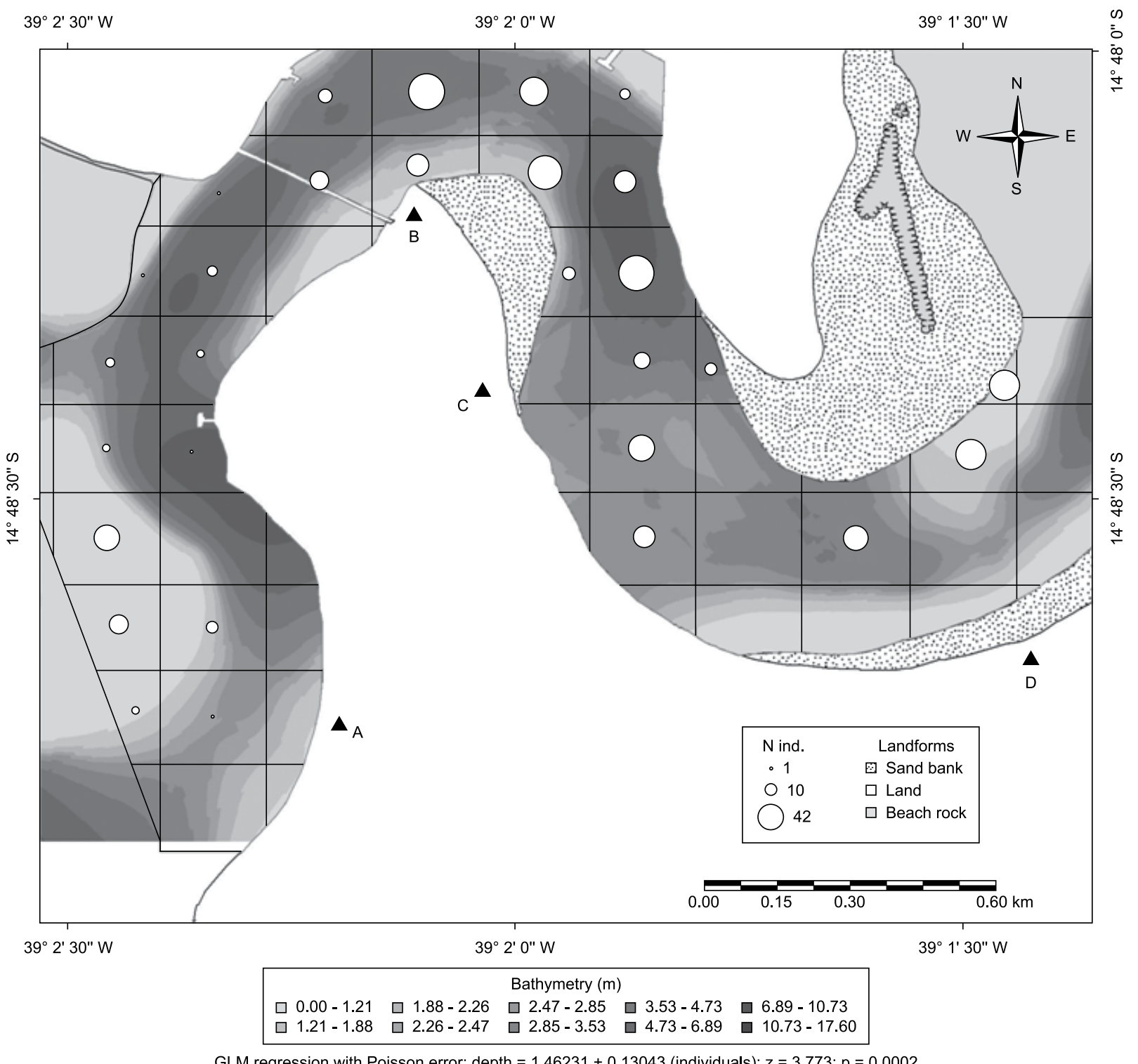

Figure 3. Number of estuarine dolphin sightings by quadrant at Pontal Bay, Ilhéus in $2006(n=335)$.

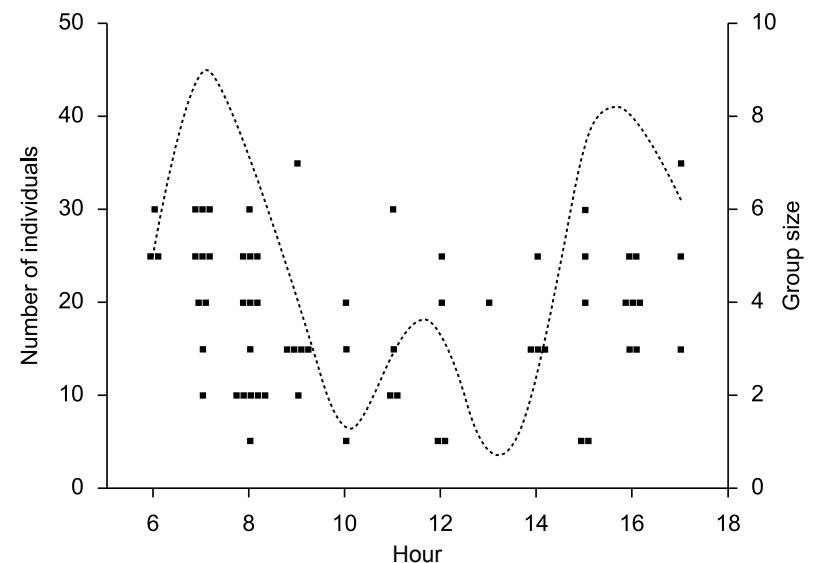

Figure 4. Expected number of individuals under random conditions (dashed line) and group size (dots) according to time at Pontal Bay, Ilhéus in 2006. The frequencies of observed individuals are based on 1,000 re-samplings of 200 scan samplings.

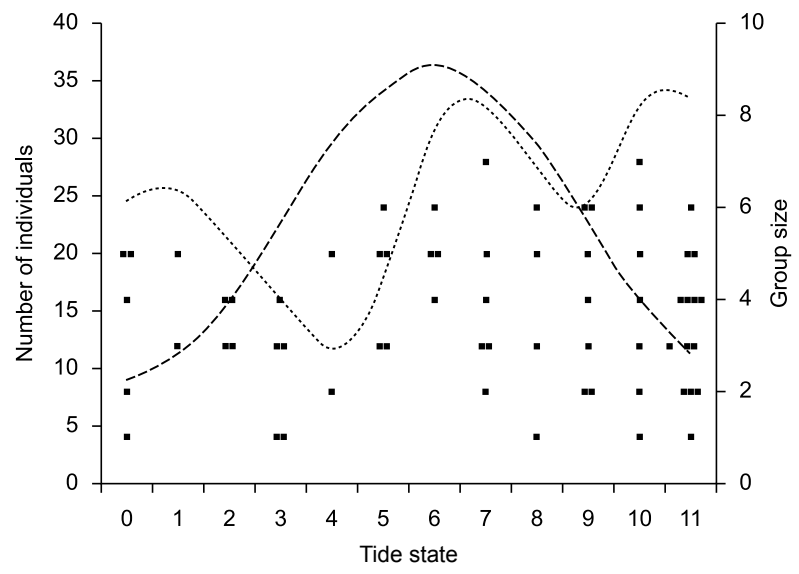

Figure 5. Number of observed individuals (dashed line) and group size (dots) according to tide state (see text for explanation) at Pontal Bay, Ilhéus in 2006. The frequencies of observed individuals are based on 1,000 re-samplings of 200 scan samplings. The relative height of the tide is symbolized by the dotted line. 


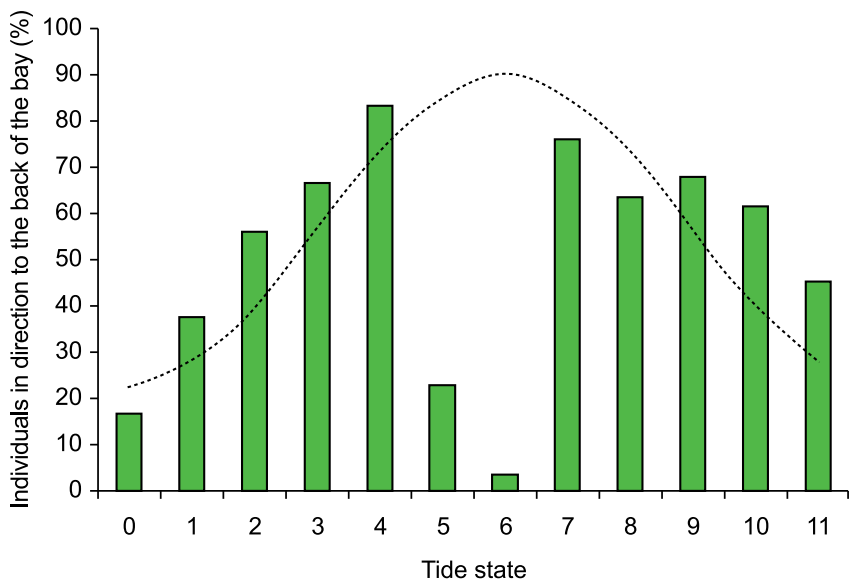

Figure 6. Proportion of individuals swimming or foraging in the direction of the back of the bay according to tide state (see text for explanation).

\section{Discussion}

Estuarine dolphins were observed in Pontal Bay in $30 \%$ of the sampling periods, indicating the importance of this area for the species. The animals were observed during the entire year except for the month of November. This observation can be explained in part by the relatively small sampling effort carried out from September to December, but several authors have noted a drastic decrease in the frequency of observation of estuarine dolphins in an adjacent area (Assis 2008, Izidoro 2009). The animals were sighted more frequently in September and October, but we cannot yet confirm if this increase corresponds to a seasonal pattern. The seasonal pattern of occurrence of estuarine dolphin has only been described for large bays like Guanabara Bay, Rio de Janeiro, and the lagoon estuary of Cananéia, São Paulo: Geise (1991) and Geise et al. (1999) observed a high frequency of estuarine dolphins throughout the year, with no seasonal pattern. Hayes (1999) recorded a higher frequency of individuals in March at Iracema Beach in Ceará and related this abundance to heavy rainfall and the large amounts of fish present in the shallow waters of the area. In Pernambuco, Araújo et al. (2007) observed a decrease in the number of individuals sighted with an increase in monthly precipitation. However, the frequency of sightings of estuarine dolphins was not related to precipitation intensity at Pontal Bay (Santos 2007). The presence of infants was observed during the entire year at Pontal Bay, as seen for other estuarine dolphin populations (Cremer 2000, Di Beneditto et al. 2001, Araújo et al. 2003, Lodi 2003b, Azevedo et al. 2005, Daura-Jorge et al. 2005).

Estuarine dolphins were more frequently present in the channel of Pontal Bay in areas greater than $3 \mathrm{~m}$ in depth. The use of such areas can occur due to the abundance of fish and a topography facilitating the capture of prey. The preferential use of estuaries and passages where prey concentrate has also been identified in Tursiops truncatus (Shane 1990, Ballance 1992) but an individual observed in a bay can also frequent offshore waters according to local bathymetric and oceanographic conditions (Bearzi 2005). Some authors have reported a higher use of areas greater than $10 \mathrm{~m}$ in depth, where food abundance is greater, for S. guianensis (Geise 1991, Cremer 2000, Simão \& Poletto 2002, Araújo et al. 2007, Azevedo et al. 2007). In Sepetiba Bay, Simão \& Poletto (2002) observed estuarine dolphins fishing in waters between 3 and $30 \mathrm{~m}$ deep, with an average depth of $13 \mathrm{~m}$, a value close to the $12 \mathrm{~m}$ found in Guanabara Bay (Azevedo et al. 2007). However, other populations use shallow areas more frequently, with depths less than $1 \mathrm{~m}$ (Geise et al. 1999), $3 \mathrm{~m}$ (Edwards \& Schnell 2001, Flores \& Bazzalo 2004, Bazzalo et al. 2008) or 6 m (Lodi 2003a,
Rossi-Santos 2006). Water depth is not a factor that can sufficiently explain the spatial distribution of the species. Habitat use is related to topography conditions and bottom substratum (Monteiro-Filho 1991). For example, Lodi (2003a) observed the species near rocky areas that are favorable for shoal enclosure, showing that estuarine dolphins change their fishing behavior due to local geomorphologic characteristics (Domit 2006).

According to Geise et al. (1999) and Lodi \& Fiori (1987), populations of several species of coastal dolphins use different parts of their home range according to the time of day, and such variation is related to the animals' activity patterns. S. fluviatilis (Gervais and Deville 1853) exhibit daily displacements, entering lakes in the morning and exiting to rivers in the afternoon (Da Silva \& Best 1996). At Pontal Bay, the highest numbers of sightings of estuarine dolphins occurred in the morning and at the end of the afternoon, confirming the findings of a previous study in the same area (Santos 2001). Geise (1991) and García \& Trujillo (2004) found similar results at Guanabara Bay and Cispatá Bay, respectively, which is notable considering that these bays are deeper and larger than Pontal Bay. Geise et al. (1999) observed that most entrances of estuarine dolphins in the Cananéia estuary occurred by 10:00 AM, while Hayes (1999) and Araújo et al. (2003) registered larger abundances in the morning at Iracema Beach and Golfinhos Bay, respectively. At Pontal Bay, the frequency of sightings of estuarine dolphins and the direction of their displacement is related to tidal movements; the animals are more frequently observed in the bay during the ebb tide and move mainly upstream during this time. Such a displacement pattern can be associated with a fishing strategy. Fewer chases (Araújo et al. 2003) and reduced foraging activity (GuilhermeSilveira 2006) were observed during high tide at Golfinhos Bay, Rio Grande do Norte, suggesting that low water depths may facilitate prey capture. Oliveira et al. (1995) and Hayes (1999) also observed more individuals during the ebb and low tide in the shallow foraging area of Iracema Beach. However, more estuarine dolphins were sighted during the flood tide at Caravelas River estuary, Bahia, which was accentuated during tides of high amplitude (Rossi-Santos 2006). The author suggests an opportunistic exploration of the direction and speed of the tide by estuarine dolphins to forage, enter and leave estuaries. Araújo et al. (2007) found no significant differences between the relative frequencies of foraging events during flood and ebb tides in four port areas of Pernambuco. At Pontal Bay, the displacement direction of most individuals follows the tidal movement: an increased proportion of individuals move toward the back of the bay during the flood, and this proportion decreases during the ebb tide. This phenomenon has also been verified for bottlenose dolphins (Tursiops truncatus, Montagu, 1821 ) in the strait estuarine channel of Kessock, Scotland (Mendes et al. 2002), where dolphins were usually sighted in the proximity of the tide intrusion front, the supposed place of fish concentration. The authors suggest a joint influence of tide, estuary configuration and estuary bathymetry to explain the concentration of cetaceans and fishes in this location. Such a conjunction of factors could explain the sometimes contradictory results found by studies that analyzed the influence of tidal state on the foraging activity and displacement of estuarine dolphins along the Brazilian coast, since the estuaries present heterogeneous hydrogeographical configurations.

Estuarine dolphins frequent Pontal Bay during most of the year, primarily for feeding purposes. According to our results, animal location and displacement are influenced by water depth, time and flow direction. The potential interaction between these variables must be further investigated. Other factors, such as the influence of hydrographic characteristics on space-temporary distribution of preys, variations in tidal range and fresh water flows from rivers, should be analyzed to better understand their influences on the use of Pontal Bay by estuarine dolphins. 


\section{Acknowledgements}

We would especially like to thank the following students for their help in data collection and their enthusiasm during observation sessions: Alfredo Gusmão, Janaína Pires, Débora Fróes, Beatriz Nunes, Paula Reis, Jussara Rezende, Maíra Rodrigues, Lucyanne Ferreira, Thaís Silva and Marlla Matos. We would also like to thank INFRAERO for providing the meteorological data; the Fundação de Apoio a Pesquisa do Estado da Bahia (FAPESB) for granting the scholarship (Term 355/2005) and financing the master's degree project (agreement 202/05); and the Postgraduate Program in Zoology of the State University of Santa Cruz for the opportunity to carry out this research.

\section{References}

ALTMANN, J. 1974. Observational study of behavior: sampling methods. Behavior 49:227-267.

ARAÚJO, J.P., ARAÚJO, M.E., SOUTO, A., PARENTE, C.L. \& GEISE, L. 2007. The influence of seasonality, tide and time of activities on the behavior of Sotalia guianensis (Van Bénéden) (Cetacea, Delphinidae) in Pernambuco, Brazil. Rev. Bras. Zool. 24:1122-1130.

ARAÚJO, J.P., PASSAVANTE, J.Z.O. \& SOUTO, A.S. 2003. Behavior of the estuarine dolphin Sotalia guianensis at Dolphin Bay, Pipa, Rio Grande do Norte. Tropical Oceanography. 31:101-112.

ASSIS, C.V.D. 2008. Comportamento alimentar e características dos grupos de boto-cinza, Sotalia guianensis (van Benéden, 1864) (Cetacea: Delphinidae) no Porto de Ilhéus, Bahia. Dissertação de Mestrado, Universidade Estadual de Santa Cruz, Ilhéus.

AZEVEDO, A.F., VIANA, S.C., OLIVEIRA, A.M. \& van SLUYS, M. 2005. Group characteristics of marine tucuxis (Sotalia fluviatilis) (Cetacea: Delphinidae) in Guanabara Bay, south-eastern Brazil. J. Mar. Biol. Assoc. 85:209-212.

AZEVEDO, A.F., OLIVEIRA, A.M., VIANA, S.C. \& van SLUYS, M. 2007. Habitat use by marine tucuxis (Sotalia guianensis) (Cetacea: Delphinidae) in Guanabara Bay, south-eastern Brazil. J. Mar. Biol. Assoc. 87:201-205.

BALLANCE, L.T. 1992. Habitat use patterns and ranges of the bottlenosed dolphin in the Gulf of California, Mexico. Mar. Mammal. Sci. 8:262-274.

BATISTA, R.L.G. 2001. Estudo dos padrões comportamentais do boto cinza Sotalia fluviatilis (Gervais, 1853) (Cetacea, Delphinidae) no litoral de Ilhéus, Bahia. Trabalho de Conclusão de Curso, Universidade Estadual de Santa Cruz, Ilhéus.

BAZZALO, M., FLORES, P.A.C. \& PEREIRA, M.G. 2008. Uso de hábitat y principales comportaminetos del Delfín gris (Sotalia guianensis, van Bénédén, 1864) en la Bahía Norte, Estado de Santa Catarina, Brasil. Mastozool. Neotrop. 15:9-22.

BEARZI, M. 2005. Aspects of the ecology and behaviour of bottlenose dolphins (Tursiops truncatus) in Santa Monica Bay, California. J. Cetacean Res. Manage. 7:75-83.

BONIN, C. 2001. A utilização de habitat pelo boto-cinza, Sotalia fluviatilis guianensis (Cetacea: Delphinidae), na porção norte do Complexo estuarino da baía de Paranaguá, Paraná. Dissertação de Mestrado, Universidade Federal do Paraná, Curitiba.

BURROUGH, P.A. \& MCDONNELL, R. 1998. Principles go geographical information systems. Oxford University Press, New York, 333p.

CREMER, M.J. 2000. Ecologia e conservação do golfinho Sotalia fluviatilis guianensis (Cetacea: Delphinidae) na Baía de Babitonga, Litoral Norte de Santa Catarina. Dissertação de Mestrado, Universidade Federal de São Carlos, São Carlos.

SILVA, V.M.F. da \& BEST, R.C 1996. Sotalia fluviatilis. Mamm. Sci. 396:1-7.

DAURA-JORGE, F.G., WEDEKIN, L.L. \& SIMÕES-LOPES, P.C. 2004. Variação sazonal na intensidade dos deslocamentos do boto-cinza,
Sotalia guianensis (Cetacea: Delphinidae), na Baía Norte da Ilha de Santa Catarina. Biotemas 17:203-216.

DAURA-JORGE, F.G., WEDEKIN, L.L., PIACENTINI, V.D. \& SIMOESLOPES, P.C. 2005. Seasonal and daily patterns of group size, cohesion and activity of the estuarine dolphin, Sotalia guianensis (Van Bénéden) (Cetacea:Delphinidae), in southern Brazil. Rev. Bras. Zool. 22:1014-1021.

DI BENEDITTO, A.P.M., RAMOS, R.M.A. \& LIMA, N.R.W. 2001. Sightings of Pontoporia blainvillei (Gervais \& D'Orbigny, 1844) and Sotalia fluviatilis (Gervais, 1853) (Cetacea) in South-eastern Brazil. Braz. Arch. Biol. Techn. 44:291-296.

DOMIT, C. 2006. Comportamento de pesca do boto-cinza na região do Complexo Estuarino-Lagunar de Cananéia/Paranaguá, Brasil. Dissertação de Mestrado, Universidade Federal do Paraná, Curitiba.

EÇA, G.F., CARVALHO, F.L., VILA NOVA, D.L.D., RODRIGUES, C.C., ASCHENBRENNER, A., SANTOS, J.B.B., SANTOS, L.L., PASSOS, G.M., GUIMARAES, F.J., FERRAZ, P., SANTOS, V.G \& BELEM, A.L. 2008. Caracterização físico-química transiente do estuário do rio Cachoeira, Ilhéus-BA, durante condição de maré de quadratura. In III Congresso Brasileiro de Oceanografia e I Congresso Ibero-Americano de Oceanografia, Associação Brasileira de Oceanografia, Fortaleza, CD-ROM.

EDWARDS, H.H. \& SCHNELL, G.D. 2001. Status and ecology of Sotalia fluviatilis in the Cayos Miskito Reserve, Nicarágua. Mar. Mammal. Sci. 17:445-472.

FIDELMAN, P.I. 2005. Contribuição para mitigação dos impactos da macrófita aquática Eichornia crassipes sobre a zona costeira da região sul da Bahia. RGCI/JICZM 4:1-5.

FLORES, P.A.C. \& BAZZALO, M. 2004. Home ranges and movement patterns of the marine tucuxi dolphin, Sotalia fluviatilis, in Baía Norte, Southern Brazil. LAJAM. 3:37-52.

FLORES, P.A.C. \& DA SILVA, V.M.F. 2009. Tucuxi and Guiana Dolphin (Sotalia fluviatilis and Sotalia guianensis). In Encyclopedia of Marine Mammals (W.F. Perrin, B. Würsig, J.G.M. Thewissen). Elsevier, Amsterdam, p.1188-1192.

GARCÍA, C. \& TRUJILLO, F. 2004. Preliminary observations on habitat use patterns of the marine tucuxis, Sotalia fluviatilis, in Cispatá Bay, Colombian Caribean coast. LAJAM 3:53-60.

GEISE, L. 1991. Sotalia guianensis (Cetacea, Delphinidae) Population in the Guanabara Bay, Rio de Janeiro, Brazil. Mammalia 55:371-379.

GEISE, L., GOMES, N. \& CERQUEIRA, R. 1999. Behaviour, habitat use and population size of Sotalia fluviatilis (Gervais, 1853) (Cetacea: Delphinidae) in the Cananéia estuary region, São Paulo. Brazil. Rev. Bras. Biol. 59:183-194.

GUILHERME-SILVEIRA, F.R. 2006. Variação diária e anual de frequência e atividade do Boto-cinza, Sotalia guianensis, em Pipa, Nordeste do Brasil. Dissertação de Mestrado, Universidade Federal do Rio Grande do Norte, Natal.

HAYES, A.J.S. 1999. Ocorrência e utilização de habitat da forma marinha do tucuxi, Sotalia fluviatilis, na Praia de Iracema, Brasil, através de observações a partir de um ponto fixo. In Relatório de licenciatura em Biologia Marinha e Pescas. Universidade do Algarve, Faro.

HUI, C.A. 1985. Undersea topography and the comparative distributions of two pelagic dolphins. Fish B-Noaa. 83:472-475.

IZIDORO, F.B. 2009. Caracterização dos grupos e brincadeiras em Boto-cinza (Sotalia guianensis) (Van Bénéden, 1864) no Porto de Ilhéus, Bahia. Dissertação de Mestrado, Universidade Estadual de Santa Cruz, Ilhéus.

LODI, L. 2003a. Seleção e uso do hábitat pelo boto-cinza, Sotalia guianensis, na baía de Paraty, Rio de Janeiro, Brasil. Bioikos 17:5-20.

LODI, L. 2003b. Tamanho e composição de grupo dos botos-cinza, Sotalia guianensis (van Bénéden, 1864) (Cetacea: Delphinidae), na Baía de Paraty, Rio de Janeiro, Brasil. Atlântica 25:135-146.

LODI, L. \& FIORI, B. 1987. Observações sobre o comportamento de golfinho rotador Stenella longirostris (Cetacea, Delphinidea) na ilha de Fernando de Noronha - Brasil. In $2^{\mathrm{a}}$ Reunião de Trabalho de Especialistas 
em Mamíferos Aquáticos da América do Sul. FBCN, Rio de Janeiro, p. $60-68$.

MANN, J. 1999. Behavioral sampling methods for cetaceans: a review and critique. Mar. Mammal Sci. 15:102-122.

MARTIN, P. \& BATESON, P.P.G. 2007. Measuring behaviour: an introductory guide. Cambridge University Press, New York, 187p.

MENDES, S., TURRELL, W., LÜTKEBOHLE, T. \& THOMPSON, P. 2002. Influence of the tidal cycle and a tidal intrusion front on the spatiotemporal distribution of coastal bottlenose dolphins. Mar Ecol-Prog Ser. 239:221-229.

MONTEIRO-FILHO, E.L.A. 1991. Comportamento de caça e repertório sonoro do golfinho Sotalia brasiliensis (Cetacea: Delphinidae) na região de Cananéia, Estado de São Paulo. Tese de Doutorado, Universidade Estadual de Campinas, Campinas.

MONTEIRO-FILHO, E.L.A. 1995. Pesca interativa entre o golfinho Sotalia fluviatilis guianensis e a comunidade pesqueira da região de Cananéia. Bol. Inst. Pesca 22:15-23.

NACIF, P.G.S., COSTA, L.M., SOADI, A., FERNANDES-FILHO, E.I., KER, J.C., COSTA, O.V. \& MOREAU, M.S. 2003. Ambientes naturais da bacia hidrográfica do rio Cachoeira. www.corredores.org. br/?pageId = adminOpenDoc\&docId = 1664 (último acesso em: 04 junho 2010).

OLIVEIRA, J.A., ÁVILA, F.J.C., JÚNIOR, T.T.A., FURTADO-NETO, M.A.A. \& MONTEIRO-NETO, C. 1995. Monitoramento do boto-cinza, Sotalia fluviatilis (Cetacea: Delphinidae) em Fortaleza, Estado do Ceará, Brasil. Arq. de Cienc. Mar. 29(1-2):28-35.

RANDI, M.A.F., RASSOLIN, P., ROSAS, F.C.W. \& MONTEIRO-FILHO, E.L.A. 2008. Padrão de cor da pele. In Biologia, Ecologia e conservação do boto-cinza (E.L.A. Monteiro-Filho \& K.D.K.A. Monteiro, eds). Páginas e Letras, São Paulo, p.11-16.

REEVES, R.R., SMITH, B. D., CRESPO, E.A. \& NOTARBARTOLO DI SCIARA, G. 2003. Dolphins, whales and porpoises: 2002-2010 conservation action plan for the world's cetaceans. International Union for Conservation of Nature - Gland, Switzerland, 139p.

REEVES, R.R., CRESPO, E.A., DANS, J.T.A., KARCZMARSKI, L., LAIDRE, K., O'CORRY-CROWE, G., PEDRAZA, S., ROJASBRACHO, L., SECCHI, E.R., SLOOTEN, E., SMITH, B.D., WANG, J.Y. \& ZHOU, K. 2008. Sotalia fluviatilis. In Red list of threatened species. Version 2010.1. (International Union for Conservation of Nature - Gland, Switzerland). www.iucnredlist.org (último acesso em: 04 junho 2010).
ROSSI-SANTOS, M.R. 2006. Ecologia comportamental do boto-cinza, Sotalia guianensis (van Bénedén, 1874) (Cetacea: Delphinidea) na região extremo sul do Estado da Bahia. Dissertação de Mestrado, Universidade Federal do Paraná, Curitiba.

ROSSI-SANTOS, M.R. \& REIS, M.S.S. 2008. Relatório do II Workshop do nordeste sobre pesquisa e conservação de Sotalia guianensis. In II Workshop do nordeste: pesquisa e conservação de Sotalia guianensis (M.R. Rossi-Santos \& M.S.S. Reis, eds). Editus, Ilhéus, Bahia, p.11-94.

SANTOS, U.A. 2001. Movimentação do boto cinza Sotalia fluviatilis (Cetacea, Delphinidae), na Baía do Pontal, Ilhéus, Bahia. Trabalho de Conclusão de Curso, Universidade Estadual de Santa Cruz, Ilhéus.

SANTOS, U.A. 2007. Uso do hábitat e atividades do boto-cinza, Sotalia guianensis (van Bénéden, 1864) (Cetacea: Delphinidae), na Baía do Pontal, Ilhéus, Bahia. Dissertação de Mestrado, Universidade Estadual de Santa Cruz, Ilhéus.

SELZER, L.A. \& PAYNE, P.M. 1988. The distribution of white-sided (Lagenorhynchus acutus) and commom dolphins (Delphinus delphis) vs. environmental features of the continental shelf of de northeastern United States. Mar. Mammal. Sci. (4):141-153.

SHANE, S.H. 1990. Behavior and ecology of the bottlenose dolphin at Sinabel Island, Florida. In The bottlenose dolphin (S. Leatherwood \& R. Reeves, eds). Academic Press, San Diego, p.245-265.

SILVA, M.A.M. 2007. Biogeoquímica dos nutrientes inorgânicos dissolvidos e biomassa fitoplanctônica no estuário do Rio Cachoeira, Ilhéus, Bahia. Dissertação de Mestrado, Universidade Estadual de Santa Cruz, Ilhéus.

SIMÃO, S.M. \& POLETTO, F.R. 2002. Áreas preferenciais de pesca e dieta do ecótipo marinho do boto-cinza (Sotalia fluviatilis) na Baía de Sepetiba, RJ. Floresta e Ambiente (9):18-25.

SIMÕES-LOPES, P.C. 1988. Ocorrência de uma população de Sotalia fluviatilis, Gervais 1853, (Cetacea: Delphinidae) no limite sul de sua distribuição, Santa Catarina, Brasil. Biotemas (1):57-62. 